\title{
Gametogenic cycle of Ophioderma januarii, a common Ophiodermatidae (Echinodermata: Ophiuroidea) in southeastern Brazil
}

\author{
Michela Borges 1,3; Leonardo Q. Yokoyama ${ }^{2} \&$ Antonia C. Z. Amaral ${ }^{2}$
}

\author{
${ }^{1}$ Museu de Zoologia, Instituto de Biologia, Universidade Estadual de Campinas. Caixa Postal 6109, 13083-970 Campinas, \\ São Paulo, Brasil. \\ 2 Laboratório de Biologia Marinha, Departamento de Zoologia, Instituto de Biologia, Universidade Estadual de Campinas. \\ Caixa Postal 6109, 13083-970 Campinas, São Paulo, Brasil. \\ ${ }^{3}$ Corresponding author. E-mail: michela_borges@yahoo.com.br
}

\begin{abstract}
This study describes the gametogenic cycle of Ophioderma januarii Lütken, 1856, a common species of ophiuroid in Southeastern Brazil. The specimens were collected during the project "Biodiversidade Bêntica Marinha no Estado de São Paulo-BIOTA/FAPESP-Bentos Marinho" (Marine benthic biodiversity in the State of São Paulo-BIOTA/ Fapesp-Marine Benthos) which was conducted off the northern coast of the state of São Paulo. Specimens were captured monthly between February 2001 and December 2002. Due to the low number of individuals the monthly data was grouped in seasons (spring to winter). A total of 101 specimens were obtained: 33 in spring, 10 in summer, 23 in autumn, and 35 in winter. The gonads of eighty-eight individuals ( 45 females, 42 males, and one hermaphrodite) were analyzed histologically. The male and female gametogenic cycles were classified into five different gonadal stages, which were analyzed separately. The reproductive pattern could be defined through histological analyses of male and female gonads, together with oocyte diameter frequency. Some general conclusions could also be reached: this is a gonochoric species that reproduces year-round but increases its gonadal activity during summer; based on the size of its mature oocytes, it has lecithotrophic development. Apparently, its recruitment is enhanced in late summer, and smaller individuals are more frequent during autumn and winter.
\end{abstract}

KEY WORDS. Gametogenesis; ophiuroid; recruitment.

Members of Ophiuroidea can adapt to different habitats, trophic levels, and biological interactions, with a high degree of heterogeneity in their reproductive biology. The reproductive period in ophiuroids usually lasts from one to three months, and occurs in spring, summer, or autumn (Boolootian 1966, Fell 1966). However, according to Hendler (1991), the conclusions of these authors were based on studies lasting less than one year. Recent studies (Morgan \& Jangoux 2002, Cisternas \& Byrne 2005, YoKoyama et al. 2008) of ophiuroid reproduction have shown that the duration and seasonality of the gametogenic phases are variable, and that brooding periods are normally longer than three months. Species from deep and warm waters may reproduce continuously (HeNDLER 1979, 1991). Reproduction is generally seasonal (in summer months) in temperate regions, while more extended in the tropics, but the data are pretty sparse. Moreover, the seasonality in some ophiuroids has been shown to be due to seasonal changes in sea temperature, photoperiod, and primary production, which are less seasonal in the tropics (HeNdLer 1991).

Hendler \& Tran (2001) related that in spite of the abundance and diversity of ophiuroids, reproduction and larval development are known for only $4 \%$ of the species. Egg size and kind of development have been also used to infer the reproductive mode (SCHOENER 1972, Hendler 1975, 1991). Usually, ophiuroids with small eggs have planktotrophic, moderate, or lecithotrophic larvae; large eggs indicate the occurrence of brooding (Hendler 1991, Hendler \& Tran 2001).

According to McEdward \& Miner (2001) lecithotrophic development, both in the plankton and benthos, is phylogenetically widespread and occurs in more families of the Ophiuroidea, included Ophiodermatidae.

Although only a small proportion of ophiuroids species have been studied, the diversity of larval forms suggests several alternative (and possibly multiple) evolutionary routes to the range of developmental patterns in ophiuroids (McEDWARD \& Miner 2001). Cisternas \& Byrne (2005) mention that there are three larval forms in Ophiuroidea: feeding (planktotrophic) ophioplutei, reduced nonfeeding (lecithotrophic) ophioplutei, and vitellaria larvae. There are two patterns of metamorphosis among echinoderms, Type I (with ophiuplutei) and Type II (lack ophioplutei) development. The significance of the two patterns has remained elusive because details of development, through metamorphosis, have been documented for only a small number of species (Cisternas \& Byrne 2005). 
Among ophiuroid families with vitellaria larvae (Type II development), the Ophiodermatidae is a widespread tropical family, with one genus in the Atlantic and several genera in the Indo-Pacific (Hender et al. 1995). However, descriptions of development are available for few species (CISTERNAs \& Byrne 2005).

Most of the species of this family, present an annual reproduction with a single spawning event, like Ophioderma apressum (Say, 1825) (Hendler 1991) and O. brevispinum (Say, 1825) (Hender \& Tyler 1986). However, species with a continuous reproductive cycle are not frequent in this family. Ophioderma januarii Lütken, 1856 is a robust species, commonly found above $120 \mathrm{~m}$ depth, inhabiting sand and mud bottons, in the Southern Brazilian coast (Borges \& Amaral 2005). There is little information about its reproduction, only a reference to the presence of mature gonads in the bursa during several months (Tommasi 1970), which would imply in a continuous reproductive pattern. So far, the reproductive state of this species remains unknown, since no histological investigation was made. Herein, we report on first study of the gametogenic cycle of $O$. januarii, by means of histological analysis over one year of gametogenesis, with the purpose of a critica1 examination on whether this species has seasonal reproduction.

\section{MATERIAL AND METHODS}

The specimens of $O$. januarii (Figs 1 and 2) were collected monthly, from February 2001 to December 2002, during the program "Biodiversidade Bêntica Marinha no Estado de São Paulo - BIOTA/FAPESP-Bentos Marinho", from depths between five and $50 \mathrm{~m}$, with a rectangular dredge and a bottom net, off the northern coast of the state of São Paulo, Brazil. The specimens used in this study were sampled in stations between $23^{\circ} 23^{\prime} 18^{\prime \prime}-23^{\circ} 58^{\prime} 10^{\prime \prime} \mathrm{S}$ and $44^{\circ} 11^{\prime} 42^{\prime \prime}-45^{\circ} 30^{\prime} 48^{\prime \prime} \mathrm{W}$ (Fig. 3).

Because of the small numbers of individuals for each sample, the data was grouped seasonally (spring, summer, autumn and winter). A total of 101 specimens of O. januarii were sampled, but only 88 analyzed due to a better conservation state. The disc diameter of each individual was measured with a digital caliper to the nearest $0.01 \mathrm{~mm}$.

Specimens were dissected and their gonads (Figs 4 and 5) were removed and the fixation method employed (70\% ethanol). Although the $70 \%$ ethanol is not the appropriated method for histological procedures of the tissues, there was no other options since the animals were already fixed in that solution when this gametogenic study was initiated.

The tissues were dehydrated in graded ethanol, and then infiltrated and embedded in glycol-methacrylate resin. The specimens were serially sectioned to 3-5 $\mu \mathrm{m}$ thickness with glass knives in a microtome. Sections were stained with toluidine blue and later analyzed by light microscopy and photographed. To generate the oocyte diameter frequency plots, 30 oocytes with a nucleus and nucleolus of each female were measured. Identification of gametogenic stages in both sexes was based on the work of Selvakumaraswamy \& Byrne (1995). Documentation of
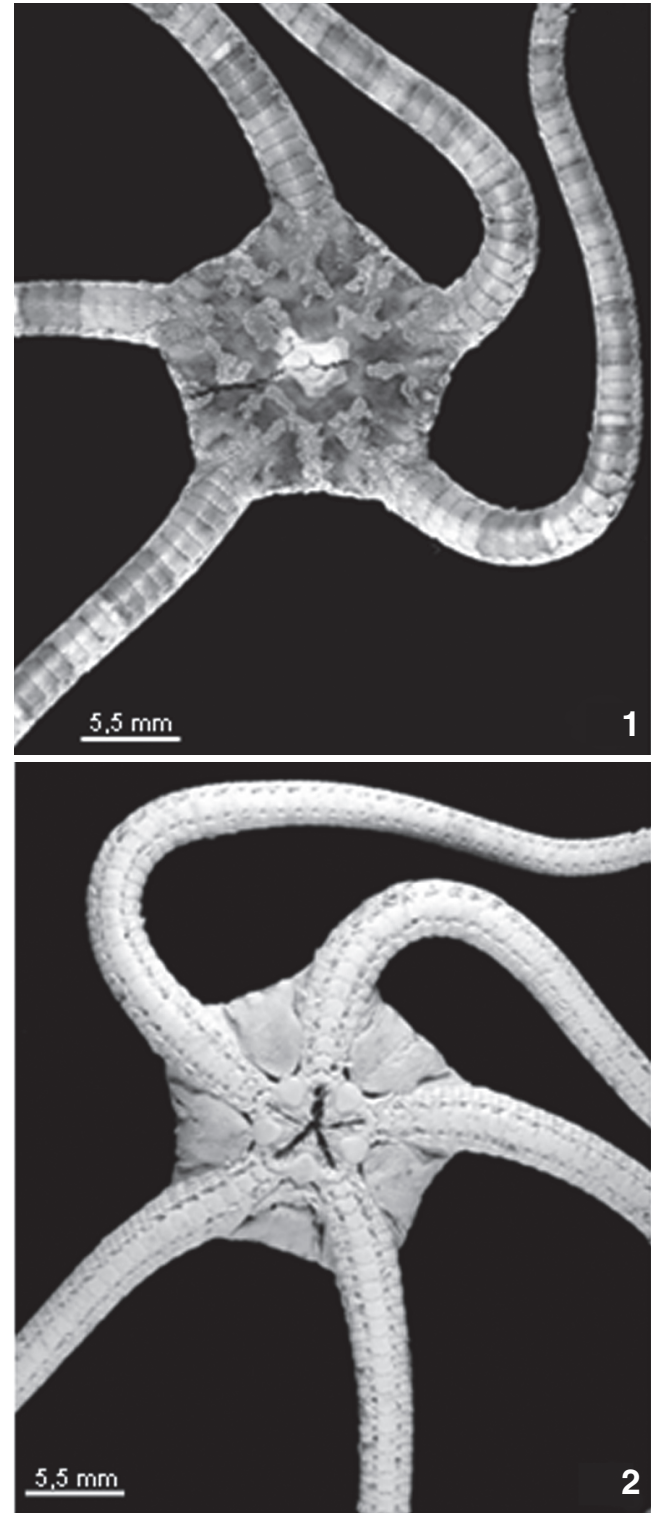

Figures 1-2. Ophioderma januarii: (1) dorsal view; (2) ventral view.

oogenesis was based on the oocyte diameter and its staining properties, according to the works of ByRne (1991), SeLVAKumaraswamy \& Byrne (1995), and Stewart \& Mladenov (1995).

Analyses of seasonal variation in the size of the species were test via ANOVA.

\section{RESULTS}

Eighty-eight individuals were analyzed, 45 female, 42 males, and one hermaphrodite. Eleven specimens could not be sexed because they either lacked gonads or were in an initial development stage (indeterminate). Two had their gonads damaged during the process of drying for image capture. 


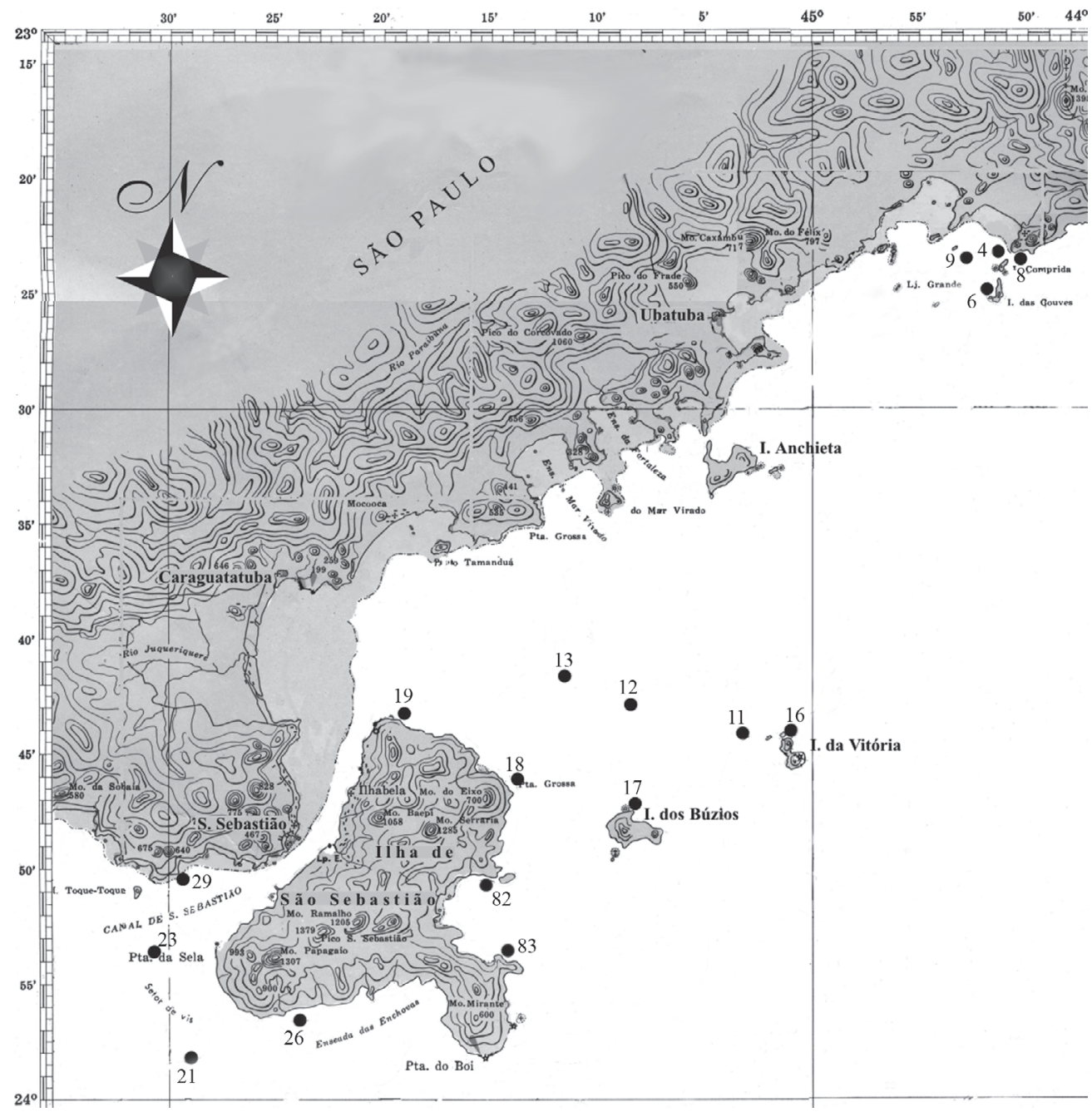

Figure 3. Studied area showing the stations of sample.

Ophioderma januarii had disc diameters between $7.38 \mathrm{~mm}$ and $25.7 \mathrm{~mm}$ with an annual mean \pm standard error of 15.22 $\mathrm{mm} \pm 4.49$. No significant seasonal differences were observed between the ophiuroid sizes $(\mathrm{F}=61.05, \mathrm{p}>0.05)$. Thus, there was a tendency to larger individuals occurring in spring and summer (mean \pm standard error: $17.57 \mathrm{~mm} \pm 5.35$ and 16.26 $\mathrm{mm} \pm 5.23$, respectively) while small specimens were more frequent in the autumn and winter months (mean \pm standard error: $13.81 \mathrm{~mm} \pm 3.77$ and $13.62 \mathrm{~mm} \pm 2.55$, respectively). However, Individuals lacking or with inconspicuous gonads were generally in the small size classes (disc diameters between 8.01 and $11.0 \mathrm{~mm}$ ) (Fig. 6). There is a predominance of individuals with growing gonads from $11.01 \mathrm{~mm}$ and mature individuals from $10.01 \mathrm{~mm}$, enhancing its occurrence in higher size classes, mainly between 23.01 and $25.0 \mathrm{~mm}$.

For both sexes of $O$. januarii, five different gonadal stages in the gametogenic cycle were observed: 1) recovering, 2) growing, 3) mature, 4) partly spawned, and 5) empty (Figs 7-22).

\section{Female}

The specimens had a disc diameter between 8.65 and 25.4 $\mathrm{mm}$ (mean \pm standard error: $15.7 \pm 4.13$ ). Approximately 30 oocytes from each female were measured (total number of oocyte: 883). Four categories were established, based on the applicable literature (Byrne 1991, Selvakumaraswamy \& Byrne 1995): 1) pre-vitellogenic oocytes, with diameter up to $75 \mu \mathrm{m}$ (mean \pm standard error $=56.27 \pm 13.11) ; 2$ ) early-vitellogenic oocytes, diameter between 75 and $150 \mu \mathrm{m}$ (mean \pm standard error $=$ $106.79 \pm 20.39$ ); 3) mid-vitellogenic oocytes, diameter between 150 and $300 \mu \mathrm{m}$ (mean \pm standard error $=227.95 \pm 45.35$ ); and 4) late-vitellogenic oocytes, completely filled with yolk and with diameter larger than $300 \mathrm{~mm}$ (mean \pm standard error $=353.31$ \pm 37.39 ). The largest oocyte had a diameter of $489.91 \mu \mathrm{m}$ and 

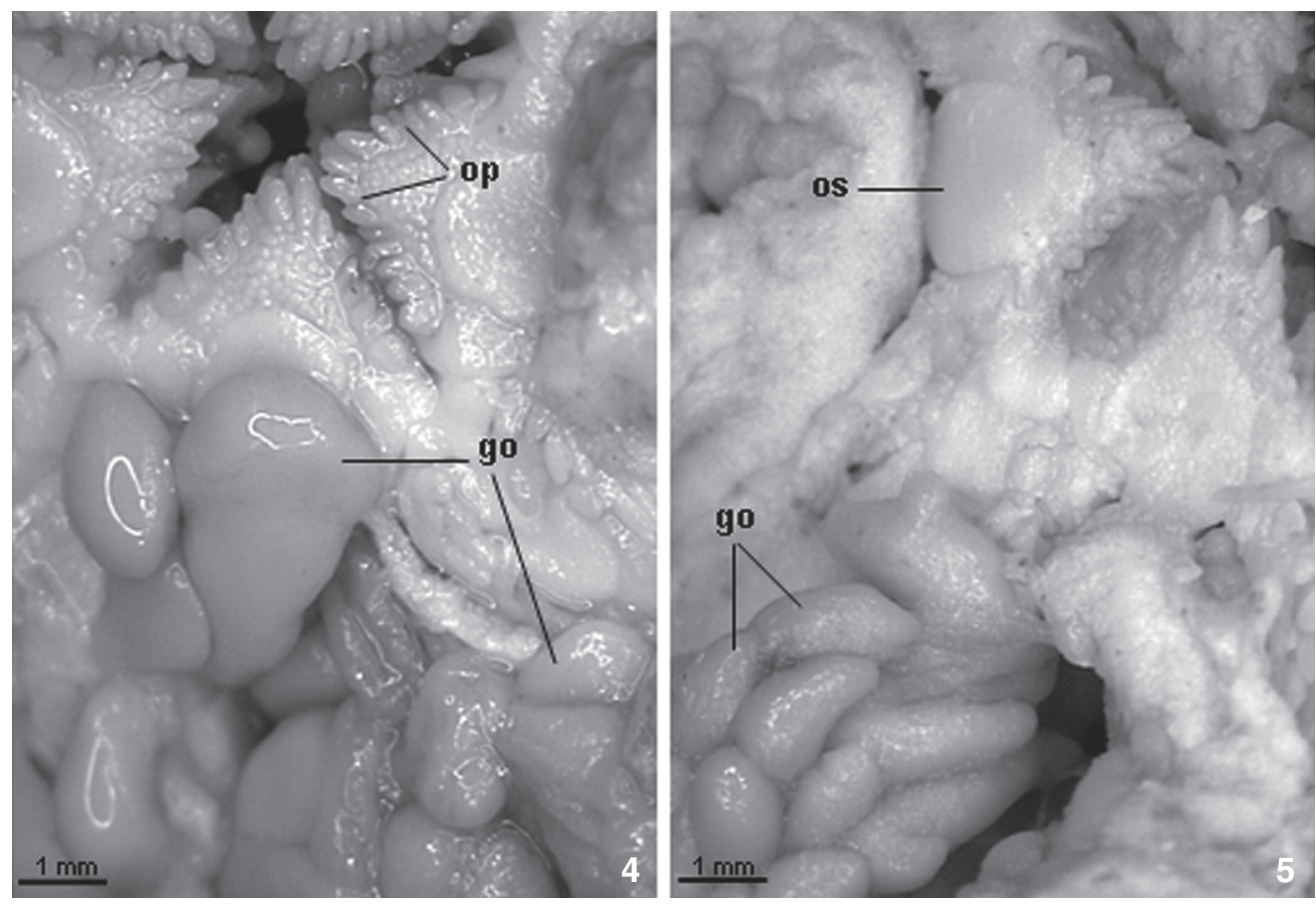

Figures 4-5. Ophioderma januarii, detail of the oral region and the gonads. (go) Gonads, (op) oral papillae, (os) oral shield.

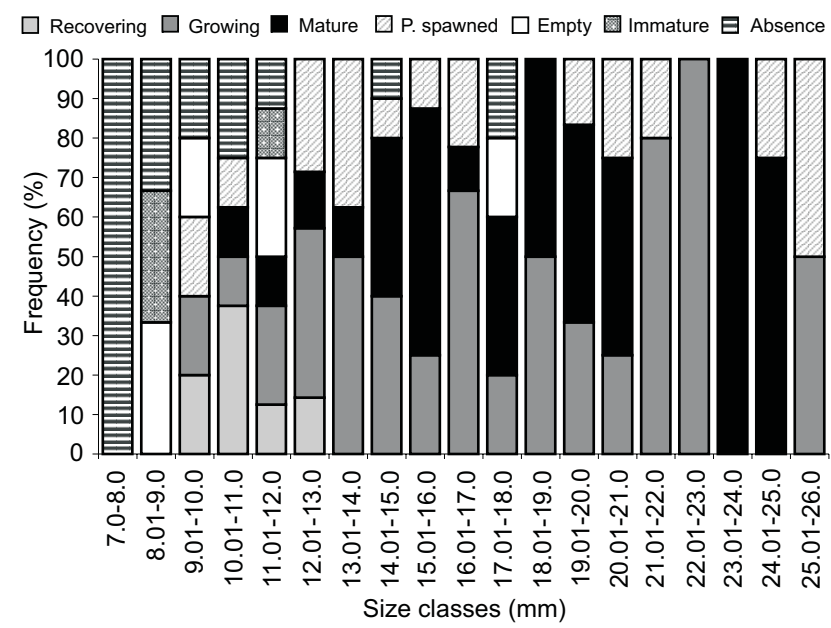

Figure 6. Frequencies for maturation stage in the different size classes $(\mathrm{mm})$ of $O$. januarii.

19 showed diameters higher than $400 \mu \mathrm{m}$. Based on these data, the following gonadal maturation stages were identified: I) Recovering: observed after the spawning. Composed of preand a few early-vitellogenic oocytes (Figs 7 and 8). The gonoduct and the lumen, filled with an unidentified substance, can be observed. II) Growing: early- and mid-vitellogenic oocytes predominating. Those that contained some late-vitellogenic oocytes, probably in an intermediate stage between the grow- ing and mature stages, were included in this classification (Figs 9 and 10). III) Mature: ovaries with predominance of latevitellogenic oocytes $(>300 \mu \mathrm{m})$. Other categories of oocytes can also be observed, however in small numbers (Figs 11 and 12). IV) Partly spawned: empty spaces in the gonad lumen. Some late-, early-, and mid-vitellogenic oocytes still present (Fig. 13). V) Empty: shrunken appearance with few pre-vitellogenic oocytes. It is difficult to observe this stage, which was recorded for the majority of females in autumn and for one female in summer (Fig. 14).

\section{Male}

In the testes sections, mature and immature cells were present together. Spermatogenesis was divided into the same gonadal maturation stages as the females: I) Recovering: small testes with spermatogonia in the peripheral region. Some spermatozoa were observed in the lumen. Individuals in this stage were found only in winter and spring (Figs 15 and 16). II) Growing: large numbers of spermatogonia adhered to the germinal epithelium. Spermatozoa columns in the initial development phase can be observed (Figs 17 and 18). III) Mature: large number of densely packed spermatozoa, fully occupying the testis lumen. Spermatogonia in the peripheral region, but in low numbers (Figs 19 and 20). IV) Partly spawned: some spermatozoa present, but with empty spaces in the testis, indicating the beginning of a spawning event (Fig. 21). V) Empty: testes are reduced, with only a few spermatogonia and spermatozoa. This stage was observed only in spring (Fig. 22). 

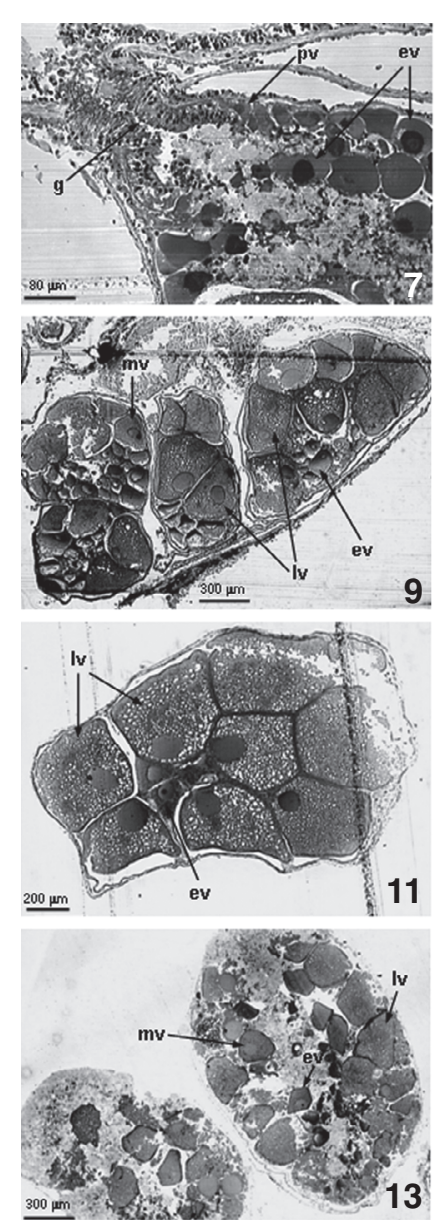
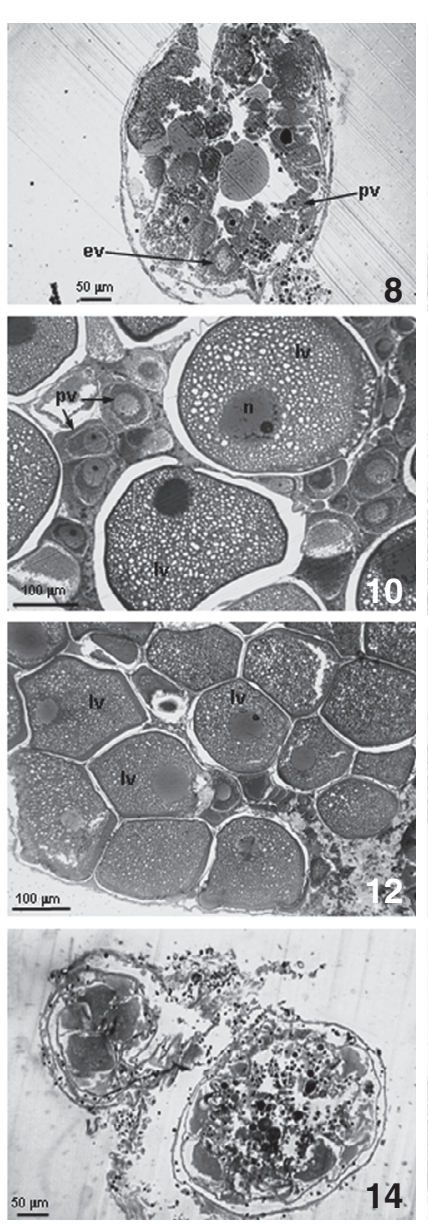
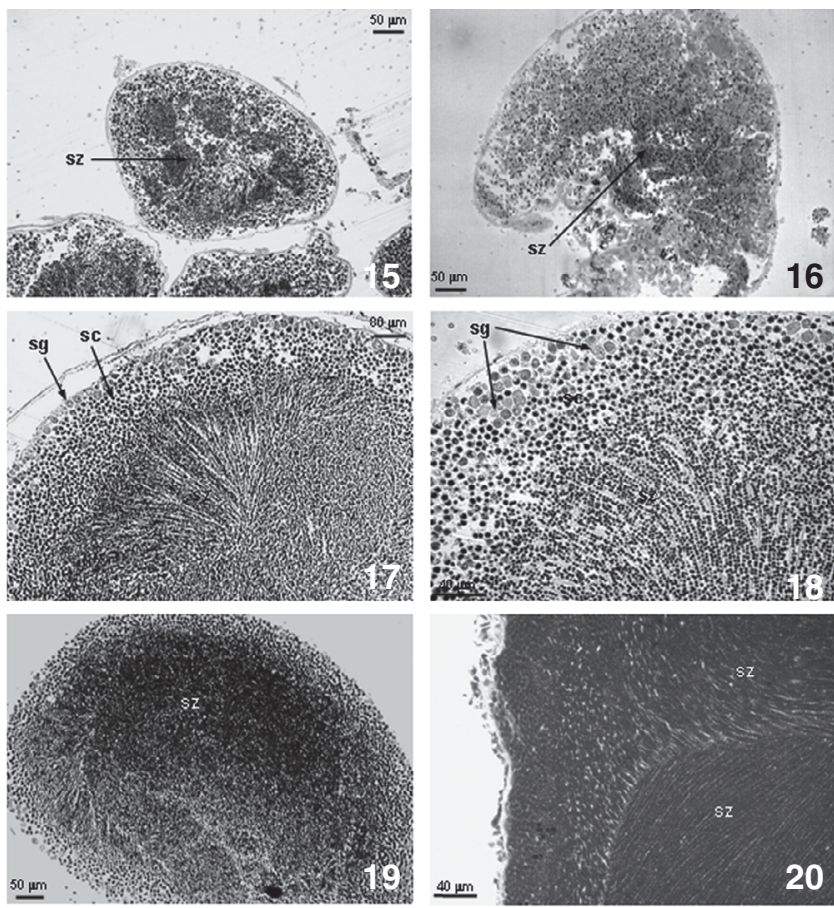

-

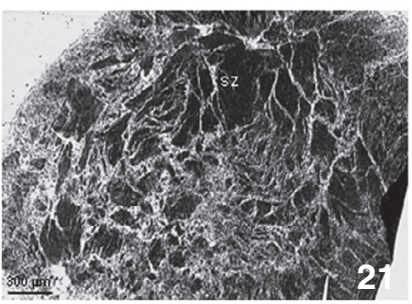

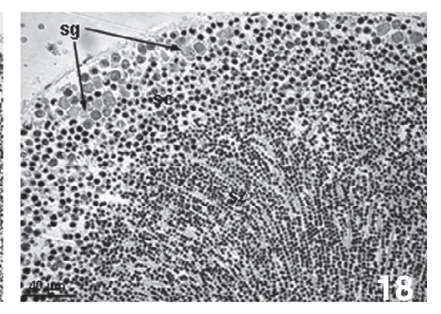

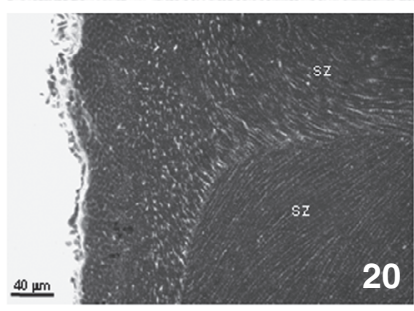

20

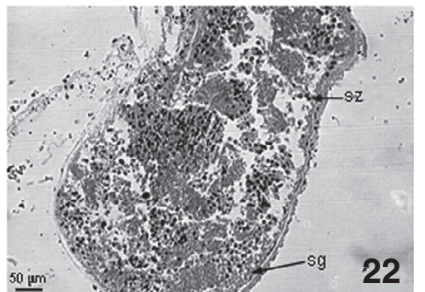

Figures 7-22. (7-14) Histological secctions of ovaries of 0 . januarii with respective gonadal maturity stages of oogenesis: (7-8) recovering; (9-10) growing; (11-12) mature; (13) partly-spawned; (14) empty. (ev) Early vitellogenic oocyte, (g) gonoduct, (Iv) late vitellogenic oocyte, (mv) mid-vitellogenic oocyte, (n) nucleous, (pv) pre-vitellogenic oocyte; (15-22) histological secctionc of tates of 0 . januarii with respective gonadal maturity stages of spermatogenesis: $(15,16)$ recovering; (17-18) growing; $(19-20)$ mature, (21) partly-spawned, (22) empty. (sc) Spermatocyte, (sg) spermatogonia, (sz) spermatozoa.

\section{Oogenic cycle}

During the spring, a large number (80\%) of females with growing gonads were present (Fig. 23). The analyses of the histological sections showed that the majority of females were in an advanced developmental stage, almost reaching maturity. However, because of the presence of pre- and early-vitellogenic oocytes, such gonads could not be considered completely mature. This result is compatible with the oocyte diameter frequency (Figs 25 to 28), because of the high percentage of early- (75-150 $\mu \mathrm{m})$, mid- (150-300 $\mu \mathrm{m})$, and late-vitellogenic oocytes $(>300 \mu \mathrm{m})$ in spring, showing the predominance of the growing stage.

Consequently, a high percentage of females would be reaching maturity in the warmer months of the year, in the spring and summer. In summer, only three females were sampled, two of which had growing gonads and one had an empty ovary (Fig. 23), which caused some difficulties in the data interpretation. The end of summer might mark the beginning of the reproductive period.

In the autumn and winter there were females in different gametogenic stages (Fig. 23), with a relative predominance of growing and mature stages. The results from the oocyte size frequencies (Figs 25-28) indicated high numbers of previtellogenic oocytes during autumn and winter, although the other oocyte categories were also present. Partly spawned and empty gonads were uncommon in the population, suggesting that in winter only a small proportion of individuals are spawning. Thus, besides the continuous occurrence of different sizes of oocytes during the entire year, i.e., a pattern of continuous reproduction, there is a period of more intense reproductive activity in the warmer months (Spring and Summer). 

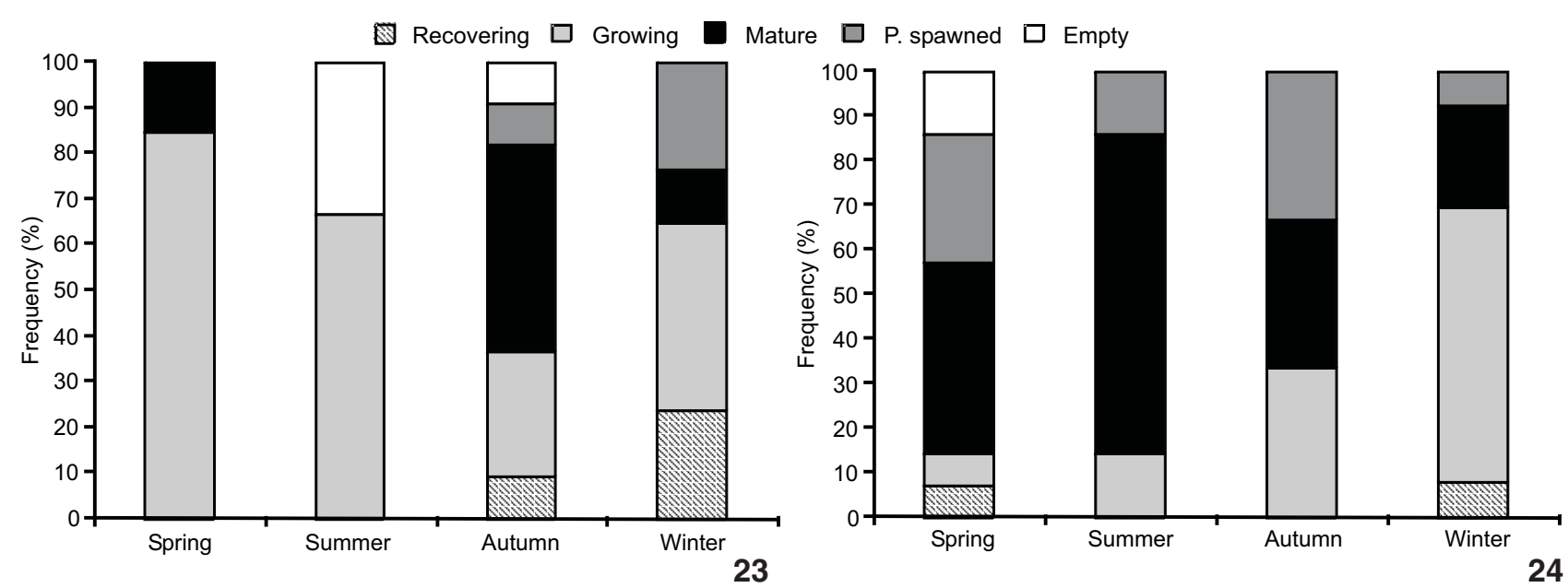

Figures 23-24. Frequencies (\%) for maturation stage in the female (23) and male (24) gametogenic cycles of O. januarii in the different seasons.

\section{Spermatogenic cycle}

Mature males were recorded year-round, especially in spring and summer (Fig. 24). The frequency of males with growing testes was very low at those seasons, and gradually increased in autumn and winter, when the number of animals in mature stages declined. Individuals with partly spawned gonads were observed year-round, especially in spring and autumn, indicating the continuous presence of active spermatozoa. Males with recovering gonads were only observed in winter and early spring.

These results are very similar to those found for females, in which reproduction occurred all year long, increasing in the warmer months of spring and summer.

\section{DISCUSSION}

The reproductive cycle of an organism is composed of gamete-developing and growing stages, alternating with spawning periods. The gonad maturity index, based on histological observations, is one of the most reliable methods to evaluate the reproductive stage of a population (Morgan \& JANGOUX 2002). This method allows comparisons between different populations and the determination of the principal periods of its gametogenic cycle. However, it is essential that the analyses be done in conjunction with that of oocyte diameter frequency, in order to better understand the reproductive process (Selvakumaraswamy \& Byrne 1995). These methods were used in the present work, and proved to be very efficient in determining the reproductive pattern of this species.

The present study found that mature individuals of $O$. januarii were present during the entire year, which implies continuous reproduction. TOMmasi (1970), referring to the species at Santos, São Sebastião, and Ubatuba, Brazil, mentioned the possibility of gonadal maturity in March, July, and early August (Tab. I). Ana M.G. Monteiro (Universidade Estadual Paulista, pers. comm.), analyzing individuals from Ubatuba, observed the presence of mature gonads in February, May, September, November, and December, which suggests a longer and continuous reproductive period (Tab. I). Both authors analyzed only the presence or absence of mature gonads in the bursae of $O$. januarii, with no other approach in histological techniques for this species in Brazil. In the present work, the small samples, especially in summer, could not be sufficient to one assume a continuous reproduction. However, this is the third time that mature individuals were observed in this period for the species and besides the low number of individuals we still can not discard the possibility of a continuous gametogenic cycle for $O$. januarii.

According to Hendler (1991), some tropical ophiuroids have a short spawning period (O. apressum and O. brevicaudum Lütken, 1856) (Tab. I); however, there seems to be a tendency toward longer reproductive periods in lower latitudes. HendLER (1991) mentioned that continuously reproducing species may show periodic fluctuations in the spawning intensity, as we observed for O. januarii. Populations of Ophioderma cinereum Müller \& Troschel, 1842 off Panama have spawning peaks in October and May, however spawning occurs year-round (Tab. I). This characteristic may be associated with continuous vitellogenesis and rapid replacement of released oocytes. Still, the majority of the Ophiodermatidae present a restricted spawning period. The reproductive cycle of O. brevispinum in Massachusetts (U.S.A.) has an annual pattern with spawning in June and July (HeNDLER \& Tyler 1986) (Tab. I). Temperature plays an important role in the reproduction of this species, compared to Ophioderma longicaudum (Retzius, 1805). The authors mentioned that differences in the reproductive pattern can be caused mainly by dissimilarities in the ambient temperature. O. brevispinum (Massachusetts) spawns in a one-month period, whereas O. longicaudum (Mediterranean) spawns for two months (July and August) (Tab. I), showing a tendency to extend gonadal growth and spawning stages in warmer waters (Hender \& Tyler 1986). 

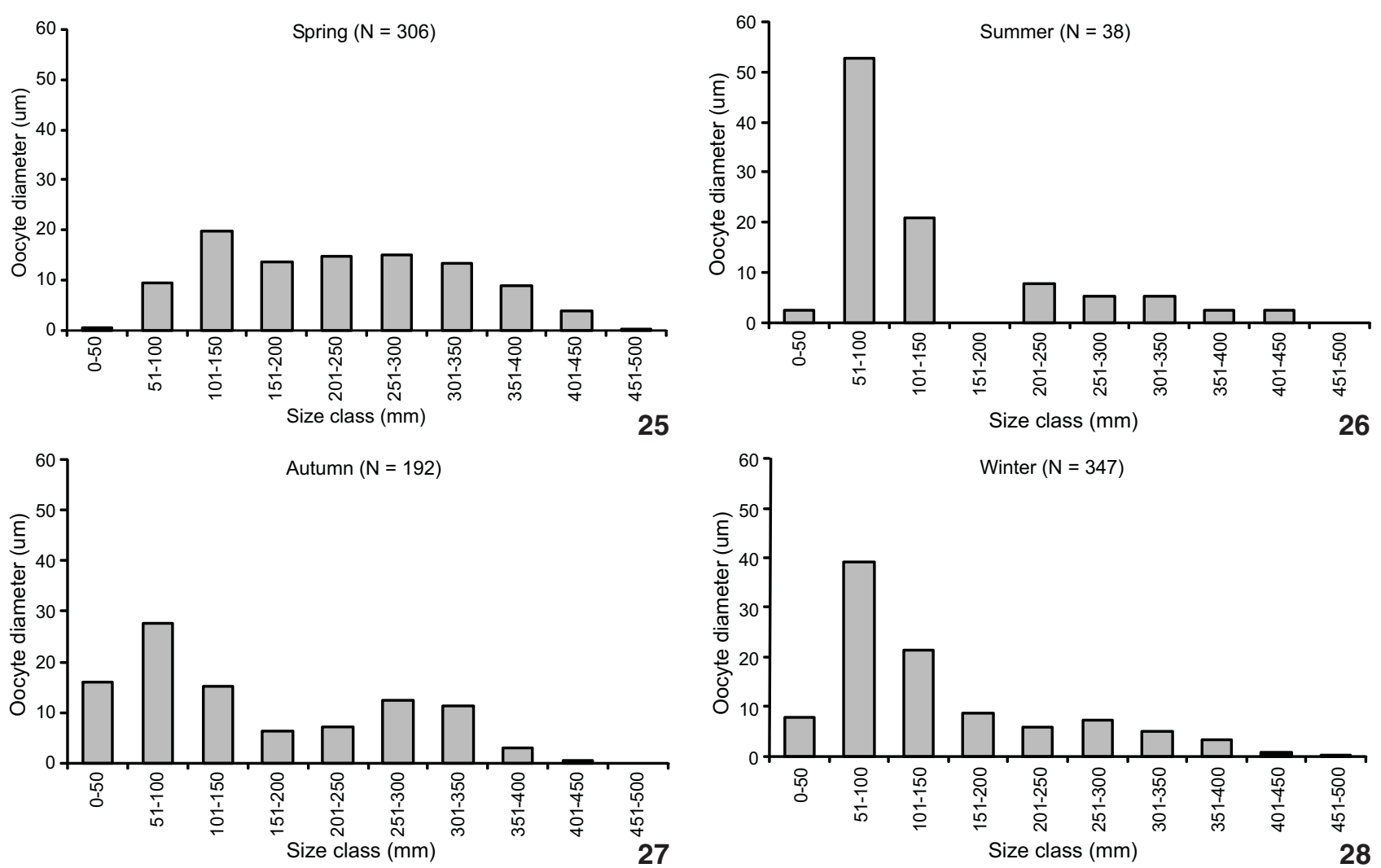

Figures 25-28. Oocyte diameter frequencies $(\%)$ for the several size classes $(\mu \mathrm{m})$ in 0 . januarii. The number of oocyte $(\mathrm{N})$ analyzed for every season are marked on top of each plot.

Table I. Reproductive spawning periods and respective sampling locations of some species of Ophioderma.

\begin{tabular}{|c|c|c|c|}
\hline Species & Reproductive Period & Location & Reference \\
\hline Ophioderma appressum (Say, 1825) & September-November & Panama & HeNDler (1991), HeNDler et al. (1995) \\
\hline Ophioderma brevicaudum Lütken, 1856 & August-November & Panama & HENDLER (1991), \\
\hline Ophioderma brevispinum (Say, 1825) & June-July & Massachusetts, USA & $\begin{array}{l}\text { HeNDLER et al. (1995), HeNDLeR \& TyLer } \\
\text { (1986), HeNDLER (1991) }\end{array}$ \\
\hline Ophioderma cinereum Müller \& Troschel, 1842 & All year (continuous) & Panama & HeNDler (1991), HeNDler et al. (1995) \\
\hline Ophioderma longicaudum (Retzius, 1805) & July-August & Mediterranean & Hendler \& Tyler (1986), HendLer (1991) \\
\hline Ophioderma rubicundum Lütken, 1856 & September-November & Panama & HeNDler (1991), HeNDler et al. (1995) \\
\hline \multirow[t]{3}{*}{ Ophioderma januarii Lütken, 1856} & March, July and August & São Paulo, Brazil & TOMMASI (1970) \\
\hline & February-December & São Paulo, Brazil & Ana M.G. Monteiro (pers. comm.) \\
\hline & All year (continuous) & São Paulo, Brazil & Present Study \\
\hline
\end{tabular}

With regard to the size of O. januarii, Tommasi (1970) sampled specimens between 1.52 and $20.5 \mathrm{~mm}$ disc diameter; Ana M.G. Monteiro (pers. comm.) between 11.7 and $22.7 \mathrm{~mm}$; and Monteiro et al. (1992) between 10.5 and $21.5 \mathrm{~mm}$. In the present study, the size varied from 7.38 to $25.7 \mathrm{~mm}$ and contrary to what MonTeiro et al. (1992) affirms, there was no significant relation between individual size and temperature. Small individuals registered in cold months for the present study are non-significant. The variation in the size of $O$. januarii does not indicate seasonality in the reproduction once mature individuals were observed during the entire study and also by Tommasi (1970) and Monteiro et al. (1992). These similarities observed for different 
years also suggest that the continuous reproductive pattern is being maintained in the population. No study of the gametogenic cycle of this species was conducted during a longer period, i.e. more than one year, and it might be a useful approach.

Based on the measurements of the late-vitellogenic oocyte diameters in O. januarii (mean diameter $353.31 \mu \mathrm{m} \pm 37.39$ ) and the relationship between the oocytes and pattern of development (Hendler 1975, 1991), it can be concluded that this species, like others Ophiodermatidae, has lecithotrophic development (McEdward \& Miner 2001, Cisternas \& Byrne 2005). The presence of a huge oocyte ( $489 \mu \mathrm{m}$ in diameter) in the gonads of $O$. januarii is uncommon for the Ophiodermatidae. Hendler \& Tyler (1986) reported that the largest oocyte of $O$. brevispinum measured had a diameter of $350 \mu \mathrm{m}$. In Ophioderma Müller \& Troschel, 1842 there is a predominance of lecithotrophy, with many species having late-vitellogenic oocytes with diameters between 300 and $350 \mu \mathrm{m}$, a size indicative of this mode of development (Hendler et al. 1995, Cisternas \& Byrne 2005). Hendere \& LitTMAn (1986), working from the relationship between reproduction, body size, and habitat for different coral-reef ophiuroids, listed eight species of Ophioderma having lecithotrophic development. Cisternas \& Byrne (2005), studding the development of other species of Ophiodermatidae, Ophiarachnella gorgonia Müller \& Troschel, 1842, demonstrated the presence of vitellaria larvae (lecithotrophy) too.

Ophioderma januarii probably has a lecithotrophic larvae (vitellaria) and the discrepant size of its late vitelogenic oocytes may reflect a poor food resource area for the larvae. Hence, the species would produce larvae with a higher amount of yolk to reduce losses in the gamete investment. A more detailed survey in the food resources for the area where the juveniles and adults occur might bring evidence to support this hypothesis.

The definition of gametogenesis period and the mode of larval development should be made with care. Generalizations based on few observations and small number of individuals should always be treated with precaution. Indeed, partial information or even results from small samples had their usefulness and researchers have to analyze the data in the appropriate form. The present work made a generalization for the reproductive pattern of Ophioderma januarii, however comparisons with other species were made (Tab. I) and problematic points, specially with the small number of individuals, were issued. Also, suggestions for improvement in future works were appointed. For the present species the continuous reproduction was only established after a careful bibliographic research. We observed that other authors noted some patterns of seasonality in the number of mature individuals that agreed with our findings. Although the number of individuals is small, especially during the summer samples, we still were able to assume that $O$. januarii is a continuous reproductive ophiuroid.

In conclusion, Ophioderma januarii reproduces year-round, with an increase in gametogenic activity in summer. The egg size indicates lecithotrophic development, and recruitment must occur in late summer. The species is reproductively active from $9 \mathrm{~mm}$ of disc diameter, with gonochoric reproduction. The mean size varies seasonally, with larger individuals predominating in spring and summer, and smaller ones in other seasons.

\section{ACKNOWLEDGMENTS}

This work was supported by the State of São Paulo Research Foundation (FAPESP) within the BIOTA/FAPESP - The Biodiversity Virtual Institute Program (www.biotasp.org.br), process 02/04298-0, and CNPq. We would like to thank the anonymous reviewers that revised this paper. Secondary address for L.Q. Yokoyama is Programa de Pós-graduação em Zoologia, Instituto de Biociências, USP, São Paulo, SP, Brazil.

\section{LITERATURE CITED}

Boolootian, R.A. 1966. Reproductive Physiology, p. 561-613. In: R.A. Boolootian (Ed.). Physiology of Echinodermata. New York, Interscience, 822p.

Borges, M. \& A.C.Z. Amaral. 2005. Classe Ophiuroidea, p. 238272. In: A.C.Z. Amaral; A.E. Rizzo \& E.P. Arruda (Eds). Manual de identificação dos invertebrados marinhos da região sudeste-sul do Brasil. São Paulo, EDUSP, vol. I, 287p.

Byrne, M. 1991. Reproduction, development and population biology of the Caribbean ophiuroid Ophionereis olivacea, a protandric hermaphrodite that broods its young. Marine Biology 111 (3): 387-399.

Cisternas, P.A. \& M. Byrne. 2005. Evolution of abbreviated development in the ophiuroid Ophiarachnella gorgonia involves heterochronies and deletions. Canadian Journal of Zoology 83 (8): 1067-1078.

Fell, H.B. 1966. The ecology of ophiuroids, p. 129-143. In: R.A. Boolootian (Ed.). Physiology of Echinodermata. New York, Interscience, 822p.

Hendler, G. 1975. Adaptational significance of the patterns of ophiuroids development. American Zoologist 15 (3): 691715.

Hendler, G. 1979. Sex-reversal and viviparity in Ophiolepis kieri, sp. nov., with notes on viviparous brittlestars from the Caribbean (Echinodermata: Ophiuroidea). Proceedings of the Biological Society of Washington 92 (4): 783-795.

Hendler, G. 1991. Echinodermata: Ophiuroidea, p. 355-511. In: A.C. Giese; J.S. Pearse \& V.B. Pearse (Eds). Reproduction of Marine Invertebrates. Pacific Grove, The Boxwood Press, vol. 6, 808p.

Hendler, G. \& B.S. LitTMan. 1986. The ploys of sex: relationships among the mode of reproduction, body size and habitats of coral-reef brittlestars. Coral Reefs 5 (1): 31-42.

Hendler, G. \& L.U. Tran. 2001. Reproductive biology of a deep-sea brittle star Amphiura carchara (Echinodermata: Ophiuroidea). Marine Biology 138 (1): 113-123.

Hendler, G. \& P.A. Tyler. 1986. The reproductive cycle of Ophioderma brevispinum (Echinodermata: Ophiuroidea). Marine Ecology 7 (2): 115-122. 
Hendler, G.; J.E. Miller; D.L. Pawson \& P.M. Kier. 1995. Sea Stars, Sea Urchins, and Allies: Echinoderms of Florida and the Caribbean. Washington, Smithsonian Institution Press, 390p. McEDWARD, L.R. \& B. Miner. 2001. Larval and life-cycle patterns in echinoderms. Canadian Journal of Zoology 79 (7): 1125-1170.

MoRgan, R. \& M. JANGOUx. 2002. Reproductive cycle and spawning induction in the gregarious brittle star Ophiothrix fragilis (Echinodermata) in the Oosterschelde (Netherlands). Invertebrate Reproduction and Development 42 (2-3): 145-155.

Monteiro, A.M.G.; M.O. Reis \& E.V. Pardo. 1992. Morfologia comparativa e distribuição batimétrica de duas espécies de Ophiuroidea, na região costeira de Ubatuba. Boletim do Instituto Oceanográfico 40 (1-2): 39-53.

Schoener, A. 1972. Fecundity and possible mode of development of some deep-sea ophiuroids. Limnology and Oceanography
17 (2): 193-199.

Selvakumaraswamy, P. \& M. Byrne. 1995. Reproductive cycle of two populations of Ophionereis schayeri (Ophiuroidea) in New South Wales. Marine Biology 124 (1): 85-97.

Stewart, B.-G. \& P.V. Mladenov. 1995. Reproductive periodicity in the euryalinid snake star Astrobrachion constrictum in a New Zealand fiord. Marine Biology 123 (3): 543-553.

Tommasi, L.R. 1970. Os ofiuróides recentes do Brasil e de regiões vizinhas. Contribuições Avulsas do Instituto Oceanográfico, Universidade de São Paulo, Série Oceanografia Biológica (20): 1-146.

Yokoyama, L.Q.; L.F.L. DuArTe \& A.C.Z. Amaral.2008 Reproductive cycle of Ophionereis reticulata (Ophiuroidea, Echinodermata) on the southeast coast of Brazil. Invertebrate Reproduction and Development 51 (2): 111-118.

Submitted: 23.VII.2008; Accepted: 11.III.2009.

Editorial responsibility: Lucélia Donatti 